\title{
Energy and ecological evaluation of ORC based geothermal CHP plant in Poland - a case study
}

\author{
Tomasz Mróz', Weronika Grabowska² \\ 1 Institute of Environmental Engineering, Poznan University of Technology, ul. Berdychowo 4, 60-965 \\ Poznań, Poland, tomasz.mroz@put.poznan.pl; \\ 2 Institute of Environmental Engineering, Poznan University of Technology, ul. Berdychowo 4, 60-965 \\ Poznań, Poland, weronika.grabowska@student.put.poznan.pl; \\ * Correspondence: tomasz.mroz@put.poznan.pl
}

\begin{abstract}
The paper presents the results of energy and environmental analysis of geothermal CHP plant operation in Polish conditions. As the most favorable, for the geothermal conditions prevailing in Poland, the variant of CHP plant based on Organic Rankine Cycle (ORC) has been taken into consideration. As the case study the existing geothermal well located in the town of Konin in the Wielkopolska voivodship has been chosen. The conceptual design of CHP plant has been proposed and evaluated from energy and environmental point of view. As energy performance criteria the non-renewable primary energy consumption has been chosen. In case of environmental performance carbon dioxide emission has been taken as evaluation criteria. The analysis has been performed for different operating conditions and three working fluids.
\end{abstract}

Keywords: energy performance, $\mathrm{CO}_{2}$ emission, cogenerated heat and power (CHP), Organic Rankin Cycle (ORC)

\section{Introduction}

The geologically confirmed geothermal energy resources in Poland are limited to low and medium temperature geothermal water. The increase in use of renewable energy sources in Poland is crucial due to the poor performance of polish power production industry, based on traditional condensing power stations fired with coal. The utilization of geothermal energy in Poland has significantly increased within last years. Unfortunately due to the available geothermal energy resources it is limited to the low temperature heat production, health care or water park operation. The intensity of heat flow in the earth shell in Poland is relatively low. Good geothermal conditions are located in West European tectonic plate, where the temperature of geothermal water in the depth of $2000 \mathrm{~m}$ reaches $80^{\circ} \mathrm{C}$.[10] The largest of the geothermal provinces in Poland is the Polish Lowland Province, which covers seven geothermal regions and covers an area of 222,000 km2. Deposit temperatures range from $30^{\circ} \mathrm{C}$ to $130^{\circ} \mathrm{C}$ at a depth of 1 to $3 \mathrm{~km}$, while general mineralization occurs in the range from 1 to $300 \mathrm{~g} /$ 1.[12] According to [10,12] geologically confirmed geothermal energy resources in Poland are located in West European tectonic plate and refer to the underground water pools of Carpatia Mountains, Sudety Mountains and Podhale - Figure 1. 


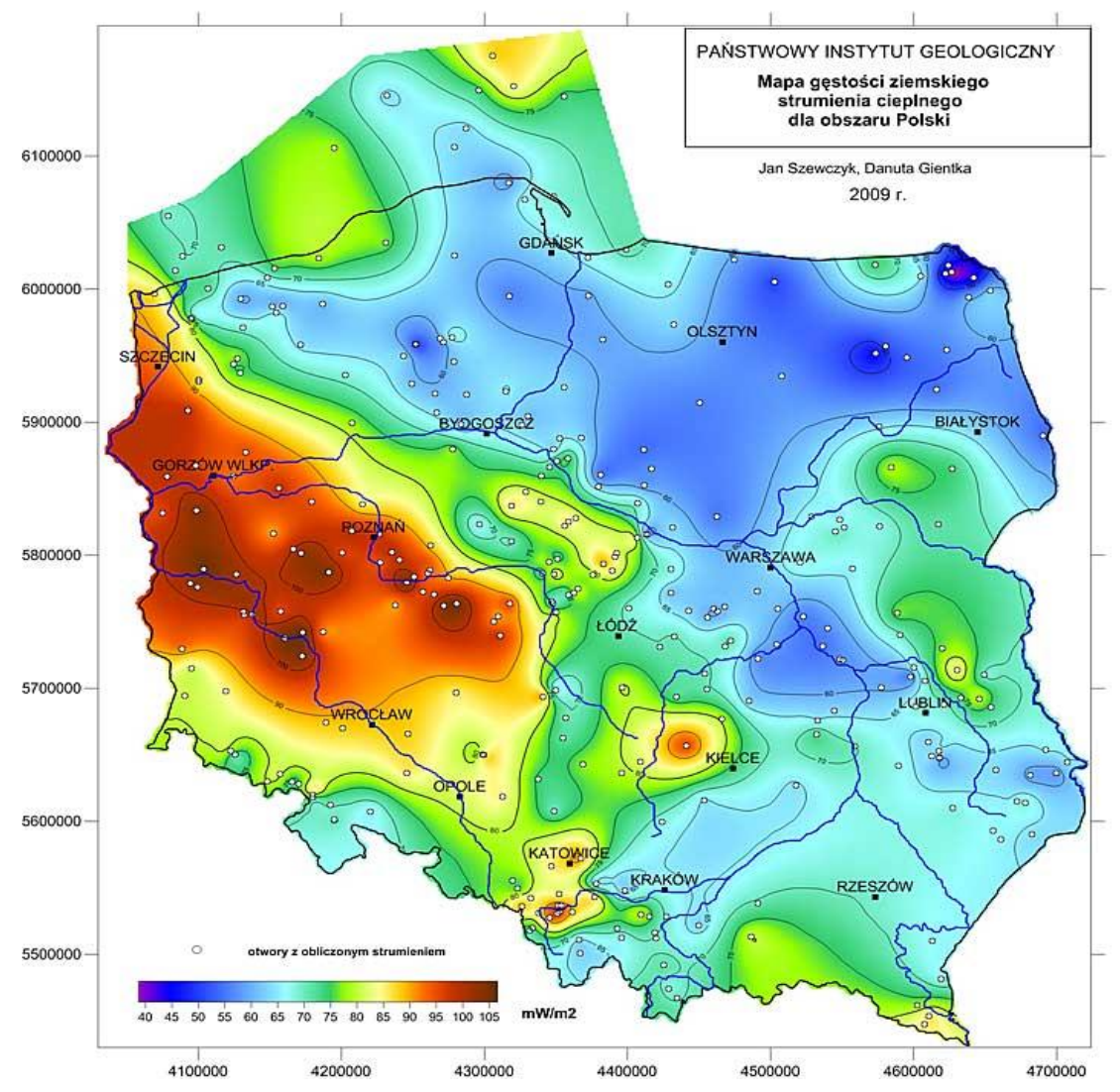

Fig. 1. The location of geologically confirmed geothermal energy resources in Poland [7]

The first geothermal heating station has been opened in Podhale region in 1994 - Geothermal Facility Banska - Biały Dunajec [17]. It was based on two wells providing water in the temperature range 80$86{ }^{\circ} \mathrm{C}$, and total flow of $670 \mathrm{~m}^{3} / \mathrm{h}$. Total heating capacity of geothermal part of the system (after refurbishment in 2014) is $40,7 \mathrm{WM}$ th.

In 2015 there were nine geothermal SPA facilities under operation in Poland. The geothermal water resources of those facilities vary between $2-200 \mathrm{~m}^{3} / \mathrm{h}$ and the temperature of geothermal water is in the range of 18 to $60{ }^{\circ} \mathrm{C}[10]$.

In recent years the increased activity in establishment of water park facilities can be observed. There were seven such facilities opened between 2006 and 2016 in Podhale region only. Those facilities are ranked as the highest geothermal heat end users. The top ranked facility is Termy Bania, which utilizes the geothermal water from single well with the depth of $2500 \mathrm{~m}$. The water temperature on the surface reaches $72{ }^{\circ} \mathrm{C}[6]$.

In the Podhalan commune of Uniejów there are thermal baths that use groundwater from the time of the Lower Cretaceous. Renewable energy is also used there for therapeutic, heating, tourist, recreational or balneological purposes. Geothermal waters in this town reach a temperature of $70^{\circ}$ C, which is their great advantage [13].

Since 2015 in Janowo, Baltic Sea region low temperature geothermal water taken from the $1200 \mathrm{~m}$ deep well is used in the production of Atlantic Salomon.

In general the temperature of geothermal water in Poland does not exceed $70-80^{\circ} \mathrm{C}$, what makes the power production or cogenerated heat and power (CHP) production in the direct solutions inefficient 
from the economical point of view [17]. It is caused by the fact that it is assumed that for the production of electricity it is profitable to use geothermal waters with a temperature of $120-150^{\circ} \mathrm{C}$.[12] Geothermal resources with temperatures above $130^{\circ} \mathrm{C}$ are found in central Poland, but they are located at a depth of over $4000 \mathrm{~m}$, therefore their extraction is not profitable.[2]

That is why as the most favorable, for the geothermal conditions prevailing in Poland, the variant of CHP plant based on Organic Rankine Cycle (ORC) has been taken into consideration.

\section{Organic Rankine Cycle in energy production}

Rankine cycle is well known thermodynamic cycle which enables production of work using heat as driving energy. In majority of cases heat is delivered in the form of chemical enthalpy of fuel and water is used as working fluid. Such systems are used in $85 \%$ of world production of electricity [8]. Unfortunately ranking cycle based on water as working fluid requires very high temperature (and pressure) of steam introduced to turbine [16]. In consequence the heat introduced to the system as driving energy is limited to intensive energy forms - fossil fuel chemical enthalpy or nuclear energy. The principle of Organic Rankine Cycle (ORC) operation is similar. The main difference lays in working fluids which in the case of ORC are organic substances characterized by high molecular weight, lower temperature of evaporation and higher pressure of steam phase. It allows for the utilization of low temperature heat as driving energy, operation in lower pressure and application of turbines with lower rotation speed [5,8]. From the technological point of view ORC is less complicated with respect to traditional $\mathrm{RC}$, it can use only one heat exchanger for heating, evaporating and overheating of working fluid. The additional heat regenerator is sometimes used for preheating liquid phase of working fluid [15]. Depending on low temperature heat source characteristic the working fluid has to be precisely selected [5]. The cost and market availability of working fluid have to be considered too [14,16]. The Organic Rankine Cycle attracted a lot of attention. This may be due to its contribution to mitigating the degradation of the ecosystem. This assessment is therefore very important and works on the basis of exergy analysis and life cycle methods [18,21]. Constantly developing power plants using the Organic Rankine Cycle are in addition to the Stirling engine, the only technology available on the market that allows the generation of electricity using low and medium temperature waste heat energy. Much effort has been put into improving the analysis techniques to find the best working fluid and ORC parameters for system configuration [9]. One of the main topics of investigations related to ORC is performance evaluation. However, adequate research on the effects of fluid charge on the operation outside the working system is still lacking. The correct liquid level in the condenser provides a large amount of working fluid, which also avoids cavitation of the pump [11]. Calculating the efficiency of both ORC and its components is not an easy task due to the lack of adequate instrumentation, inaccurate measurements and uncertainty as to the thermodynamic properties of the working fluid. This can have a significant impact on the final results of calculations, especially for complex fluids, with a small temperature drop in expansion [20].

Lubricating oil can help reduce the friction loss of the expander and prevent leaks. However, it affects the characteristics of the Organic Rankine cycle by mixing with a clean working fluid due to the lack of an oil separator. This oil improves the behavior of the pump, however, it exacerbates the power of the expander shaft as well as the electrical power. The thermal efficiency is not sensitive to the lubricating oil ratio for the degree of superheat higher than $10^{\circ} \mathrm{C}$ [3]. Due to the excellent results of 
the high-temperature Organic Rankine cycle in the use of renewable energy and industrial heat recovery, it has recently attracted a lot of interest. During the selection of working fluids, their stability is very important due to possible degradation at high temperatures. Studies have shown that siloxanes are a good choice for high-temperature ORCs, but there is not enough research on their thermal stability [1].

The possibility of use of existing low temperature geothermal energy source located in Konin, Poland has been the basis for conceptual design of ORC based co-generated heat and power plant.

\section{The conceptual design of CHP plant based on ORC}

The conceptual design of geothermal CHP plant has been settled on existing geothermal heat source located in the town of Konin in Wielkopolska voivodship, central part of Poland. The basic data of the source are listed in table 1.

Table 1. The basic data of geothermal heat source in the town of Konin [19]

\begin{tabular}{|c|c|c|}
\hline Depth of geothermal well & {$[\mathrm{m}]$} & 2660 \\
\hline Temperature of geothermal water in the layer & {$\left[{ }^{\circ} \mathrm{C}\right]$} & 97,5 \\
\hline $\begin{array}{l}\text { Temperature of geothermal water on the } \\
\text { surface }\end{array}$ & {$\left[{ }^{\circ} \mathrm{C}\right]$} & 92,0 \\
\hline Mineralization of geothermal water $(\mathrm{Cl}-\mathrm{Na})$ & {$[\%]$} & 15,04 \\
\hline Mineralization of geothermal water $(\mathrm{Cl}-\mathrm{Na})$ & {$[\mathrm{g} / \mathrm{kg}]$} & 150,4 \\
\hline Specific heat of geothermal water & {$[\mathrm{kJ} / \mathrm{kg} \mathrm{K}]$} & 3,549 \\
\hline Geothermal water flow & {$\left[\mathrm{m}^{3} / \mathrm{h}\right]$} & 114,0 \\
\hline
\end{tabular}

The flow diagram of proposed geothermal CHP plant based on ORC is shown in Fig. 2. It consists of ORC part responsible for electricity production and heat exchanger located downstream from evaporator responsible for useable heat production. The characteristic points of working fluid thermodynamical properties for ORC cycle have been plotted in Fig. 3. 


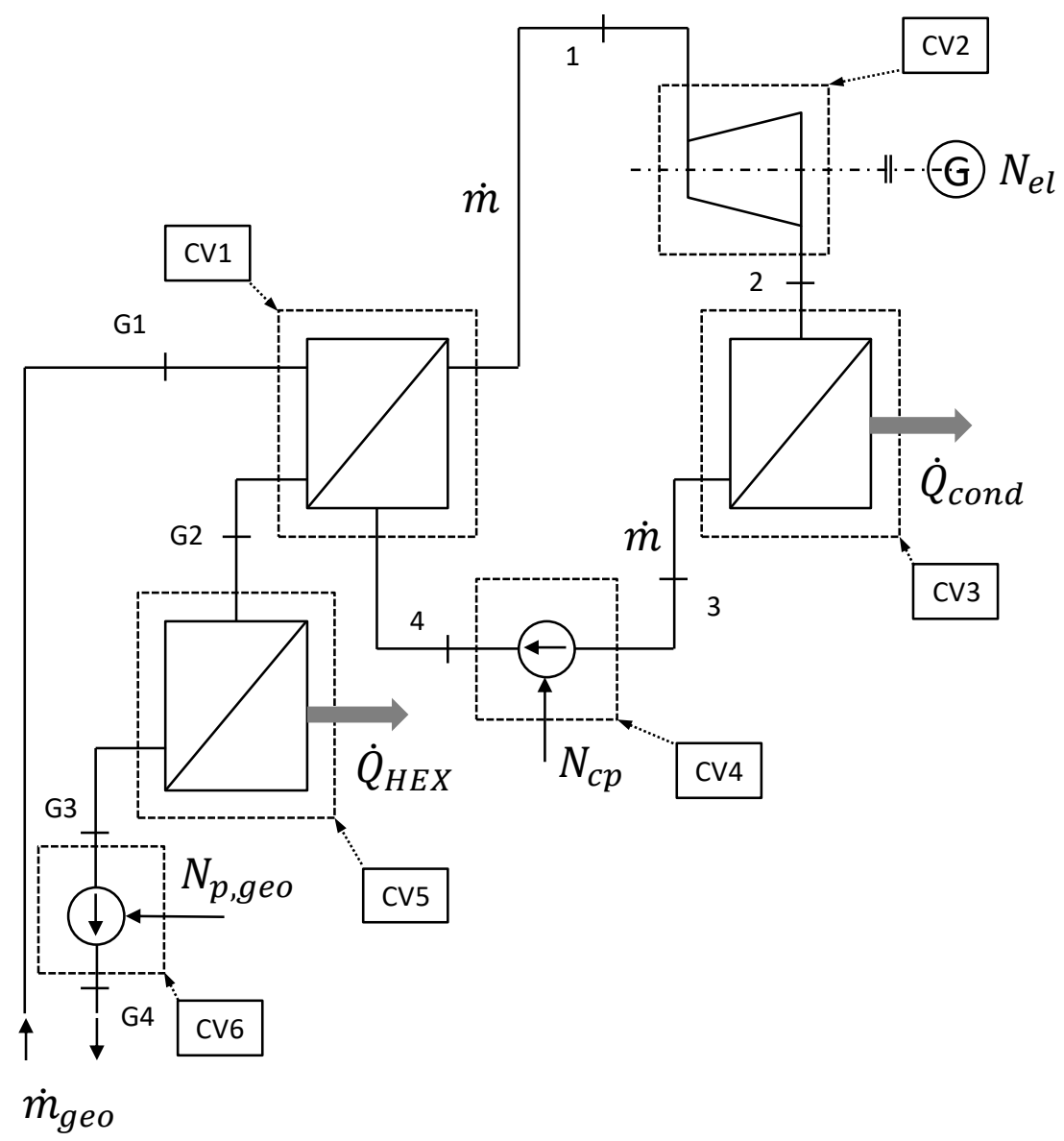

Fig. 2. The flow diagram of geothermal CHP plant based on ORC

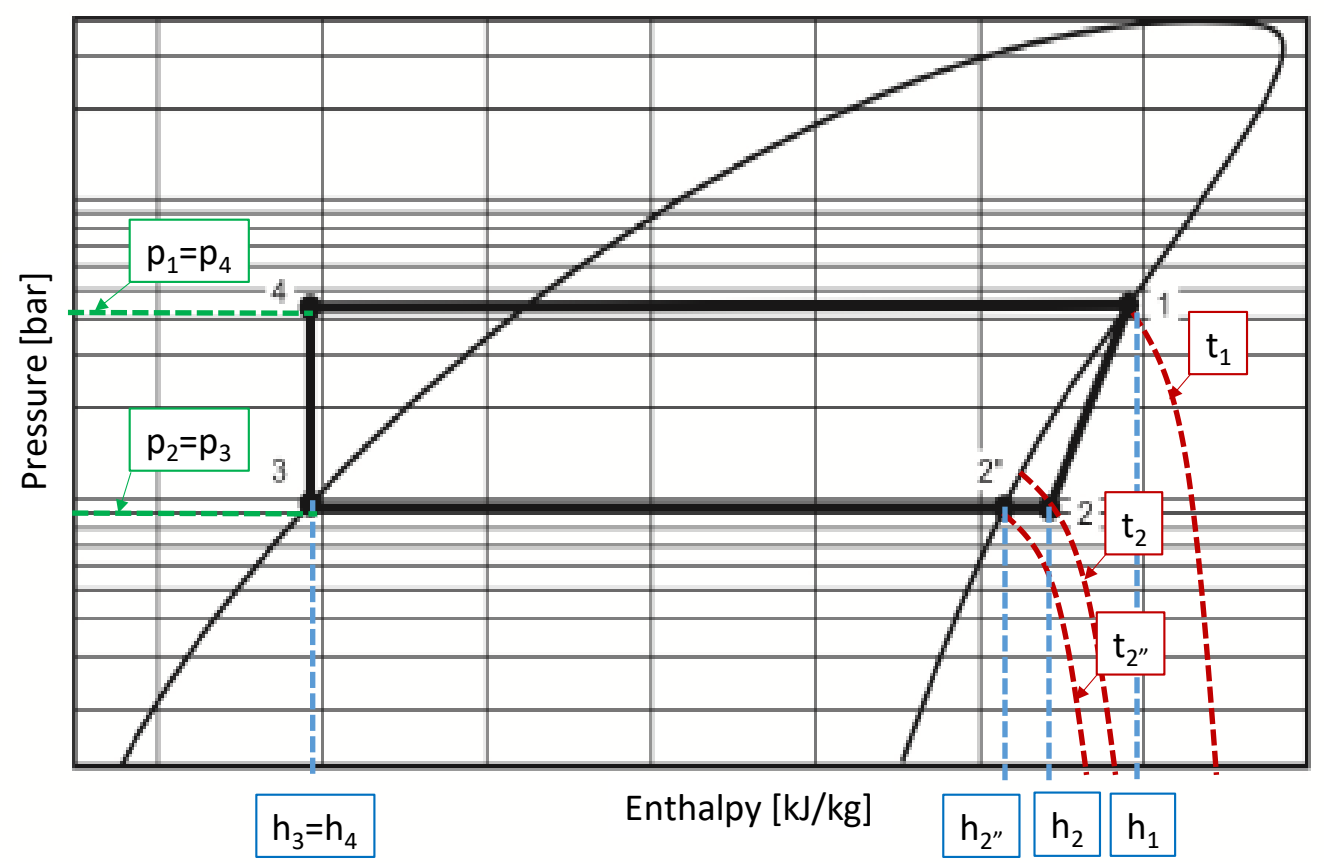

Fig. 3. Characteristic points of working fluid thermodynamic properties for ORC cycle 
In order to evaluate the energy and ecological performance for the proposed ORC based CHP plant the First Law of Thermodynamics has been employed.

\section{Calculation model}

The calculations performed were settled on the First Law of Thermodynamics and energy balance equations derived for control volumes (CVs) covering main system elements.

Energy balance equation for evaporator (CV1):

$$
\begin{gathered}
\dot{E}_{\text {in }}=\dot{E}_{\text {out }} \\
\dot{E}_{\text {in }}=H_{G 1}=\dot{m}_{g e o} \cdot h_{G 1} \\
\dot{E}_{\text {out }}=H_{G 2}=\dot{Q}_{\text {evap }}+\dot{m}_{g e o} \cdot h_{G 2} \\
\dot{Q}_{\text {evap }}=\dot{m} \cdot\left(h_{1}-h_{4}\right) \\
\dot{m} \cdot\left(h_{1}-h_{4}\right)=\dot{m}_{g e o} \cdot\left(h_{G 1}-h_{G 2}\right) \\
\dot{Q}_{\text {evap }}=\dot{m}_{g e o} \cdot\left(h_{G 1}-h_{G 2}\right) \\
\dot{Q}_{\text {evap }}=\dot{m}_{g e o} \cdot c_{w} \cdot\left(t_{G 1}-t_{G 2}\right)
\end{gathered}
$$

Where:

$$
\begin{array}{lll}
\dot{m} & - & \text { mass flow of ORC working fluid, } \mathrm{kg} / \mathrm{s} \\
\dot{m}_{g e o} & - & \text { mass flow of geothermal water, } \mathrm{kg} / \mathrm{s} \\
h_{G, i} & - & \text { specific enthalpies of geothermal water, } \mathrm{kJ} / \mathrm{kg} \\
h_{i} & - & \text { specific enthalpies of ORC working fluid, } \mathrm{kJ} / \mathrm{kg} \\
t_{G, i} & - & \text { temperatures of geothermal water, }{ }^{\circ} \mathrm{C} \\
c_{w} & - & \text { specific heat of geothermal water, } \mathrm{kJ} / \mathrm{kg}{ }^{\circ} \mathrm{C} \\
\dot{Q}_{\text {evap }} & - &
\end{array}
$$

Energy balance equation for turbine (CV2):

$$
\begin{gathered}
\dot{E}_{\text {in }}=\dot{E}_{\text {out }} \\
\dot{E}_{\text {in }}=H_{1}=\dot{m} \cdot h_{1}
\end{gathered}
$$




$$
\begin{gathered}
\dot{E}_{\text {out }}=N_{i}+H_{2}=N_{i}+\dot{m} \cdot h_{2} \\
N_{i}=H_{1}-H_{2}=\dot{m} \cdot\left(h_{1}-h_{2}\right) \\
h_{2}=h_{1}-\eta_{i} \cdot\left(h_{1}-h_{2 s}\right) \\
N_{i}=\dot{m} \cdot \eta_{i} \cdot\left(h_{1}-h_{2 s}\right) \\
N_{e l}=\dot{m} \cdot \eta_{i} \cdot\left(h_{1}-h_{2 s}\right) \cdot \eta_{g}=N_{i} \cdot \eta_{e m}
\end{gathered}
$$

Where:

$N_{i} \quad-\quad$ internal power of ORC turbine, $\mathrm{kW}$

$N_{e l} \quad-\quad$ electrical power of ORC turbine, $\mathrm{kW}$

$\eta_{i} \quad-\quad$ internal energy efficiency of ORC turbine,

$\eta_{e m} \quad-\quad$ electro-mechanical energy efficiency of ORC turbine,

Energy balance equation for condenser (CV3):

$$
\begin{gathered}
\dot{E}_{\text {in }}=\dot{E}_{\text {out }} \\
\dot{E}_{\text {in }}=H_{2}=\dot{m} \cdot h_{2} \\
\dot{E}_{\text {out }}=\dot{Q}_{\text {cond }}+H_{3}=\dot{Q}_{\text {cond }}+\dot{m} \cdot h_{3} \\
\dot{Q}_{\text {cond }}=\dot{m} \cdot\left(h_{2}-h_{3}\right)
\end{gathered}
$$

Where:

$\dot{Q}_{\text {cond }} \quad-\quad$ heat flux of condenser, $\mathrm{kW}$

Energy balance equation for circulation pump (CV4):

$$
\begin{gathered}
\dot{E}_{\text {in }}=\dot{E}_{\text {out }} \\
\dot{E}_{\text {in }}=H_{3}+N_{c p, i}=\dot{m} \cdot h_{3}+N_{c p, i} \\
\dot{E}_{\text {out }}=H_{4}=\dot{m} \cdot h_{4} \\
N_{c p, i}=H_{4}-H_{3}=\dot{m} \cdot\left(h_{4}-h_{3}\right)
\end{gathered}
$$




$$
N_{c p}=\frac{N_{c p, i}}{\eta_{c p, e m}}=\dot{m} \cdot \frac{v \cdot\left(p_{4}-p_{3}\right)}{\eta_{c p, i} \cdot \eta_{c p, e m}}
$$

Where:

$\begin{array}{lll}N_{c p, i} & - & \text { internal power of ORC circulating pump, } \mathrm{kW} \\ N_{c p} & - & \text { electrical power of ORC circulating pump, } \mathrm{kW} \\ \eta_{c p, i} & - & \text { internal energy efficiency of ORC circulating pump, } \\ \eta_{c p, e m} & - & \text { electro-mechanical energy efficiency of ORC circulating pump, } \\ v & - & \text { specific volume of ORC working fluid, } \mathrm{m}^{3} / \mathrm{kg} \\ p_{i} & & \end{array}$

Energy balance equation for heat exchanger (CV5):

$$
\begin{gathered}
\dot{E}_{\text {in }}=\dot{E}_{\text {out }} \\
\dot{E}_{\text {in }}=H_{G 2}=\dot{m}_{g e o} \cdot h_{G 2} \\
\dot{E}_{\text {out }}=\dot{Q}_{H E X}+H_{G 3}=\dot{Q}_{H E X}+\dot{m}_{g e o} \cdot h_{G 3} \\
\dot{Q}_{H E X}=\dot{m}_{g e o} \cdot\left(h_{G 2}-h_{G 3}\right) \\
\dot{Q}_{H E X}=\dot{m}_{g e o} \cdot c_{w} \cdot\left(t_{G 2}-t_{G 3}\right)
\end{gathered}
$$

Where:

$\dot{Q}_{H E X} \quad$ - heat flux of district heating heat exchanger, $\mathrm{kW}$

The set of energy balance equations listed above has been solved and used as energy analysis tool for proposed ORC cogenerated heat and power plant.

\section{Results and discussion}

The calculations have been performed using the Excel based calculation tool [4]. It has been assumed that the temperatures of geothermal water entering and leaving evaporator $(\mathrm{CV}-1)$ are $t_{G 1}=90^{\circ} \mathrm{C}$ and $t_{G 2}=75^{\circ} \mathrm{C}$. It has been also assumed that the overall efficiency of turbine and generator is $80 \%$ and overall efficiency of working fluid and geothermal water pumps are $70 \%$. The calculations have been performed for three working fluids: R123, R134a and R227. In order to evaluate the production capability of the system the following operational parameters have been changed in calculations: 
evaporation temperature $t_{1}=75^{\circ} \mathrm{C}$ and $t_{1}=70^{\circ} \mathrm{C}$, condensation temperature $t_{2 \prime \prime}=25^{\circ} \mathrm{C}$ and $t_{2 \prime \prime}=$ $30^{\circ} \mathrm{C}$ and temperature of geothermal water leaving the heat exchanger $t_{G 3}=30^{\circ} \mathrm{C}, t_{G 3}=$ $35^{\circ} \mathrm{C}$ and $t_{G 3}=40^{\circ} \mathrm{C}$. The thermodynamic properties of working fluids in characteristic points of ORC have been imported from Solkane 8.0 selection software. Table 2 presents the example of calculation data for working fluid R123 and following thermal parameters $t_{1}=75^{\circ} \mathrm{C}, t_{2 \prime \prime}=$ $25^{\circ} \mathrm{C}, t_{G 3}=30^{\circ} \mathrm{C}$, and energy balance results are shown in Fig. 4.

Table 2. The thermodynamic properties of characteristic points for R123

\begin{tabular}{ccccc}
\hline \multirow{2}{*}{ Point } & $\mathrm{p}$ & $\mathrm{t}$ & $\mathrm{v}$ & $\mathrm{h}$ \\
\cline { 2 - 5 } & {$[\mathrm{bar}]$} & {$\left[{ }^{\circ} \mathrm{C}\right]$} & {$\left[\mathrm{dm}^{3} / \mathrm{kg}\right]$} & {$[\mathrm{kJ} / \mathrm{kg}]$} \\
\hline 1 & 4,32 & 75,00 & 38,54 & 427,00 \\
\hline 2 & 0,92 & 37,81 & 176,48 & 406,79 \\
\hline $2 \mathrm{~s}$ & 0,92 & 30,75 & 171,81 & 401,74 \\
\hline $2{ }^{\prime \prime}$ & 0,92 & 25,00 & 167,97 & 397,66 \\
\hline 3 & 0,92 & 25,00 & 0,68 & 227,01 \\
\hline 4 & 4,32 & 25,31 & 0,68 & 227,34 \\
\hline
\end{tabular}

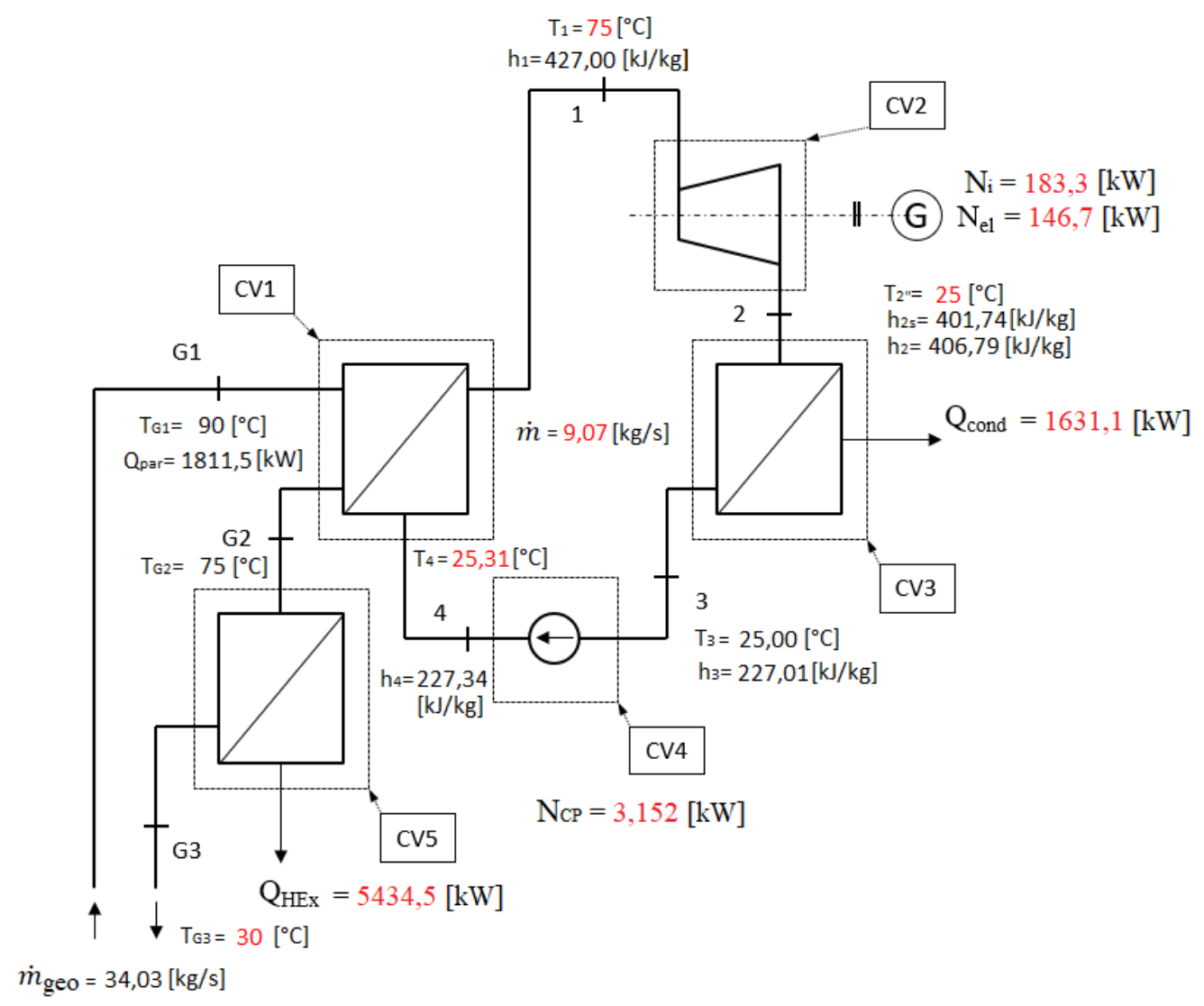

Fig. 4. Printscreen of Excel calculation tool for working fluid R123 and thermal parameters: $t_{1}=75^{\circ} \mathrm{C}, t_{2^{\prime \prime}}=25^{\circ} \mathrm{C}, t_{\mathrm{G}} 3=30^{\circ} \mathrm{C}$. 
Table 3 presents the example of calculation data for working fluid R134a and following thermal parameters $t_{1}=75^{\circ} \mathrm{C}, t_{2 \prime \prime}=30^{\circ} \mathrm{C}, t_{G 3}=35^{\circ} \mathrm{C}$, and energy balance results are shown in Fig. 5.

Table 3. The thermodynamic properties of characteristic points for R134a

\begin{tabular}{ccccc}
\hline \multirow{2}{*}{ Point } & $\mathrm{p}$ & $\mathrm{t}$ & $\mathrm{v}$ & $\mathrm{h}$ \\
\cline { 2 - 5 } & {$[\mathrm{bar}]$} & {$\left[{ }^{\circ} \mathrm{C}\right]$} & {$\left[\mathrm{dm}^{3} / \mathrm{kg}\right]$} & {$[\mathrm{kJ} / \mathrm{kg}]$} \\
\hline 1 & 23,64 & 75,00 & 7,50 & 429,11 \\
\hline 2 & 7,70 & 30,00 & 26,25 & 412,01 \\
\hline $2 \mathrm{~s}$ & 7,70 & 30,00 & 25,61 & 407,74 \\
\hline $2{ }^{\prime \prime}$ & 7,70 & 30,00 & 26,65 & 414,69 \\
\hline 3 & 7,70 & 30,00 & 0,84 & 241,83 \\
\hline 4 & 23,64 & 31,33 & 0,84 & 243,75 \\
\hline
\end{tabular}

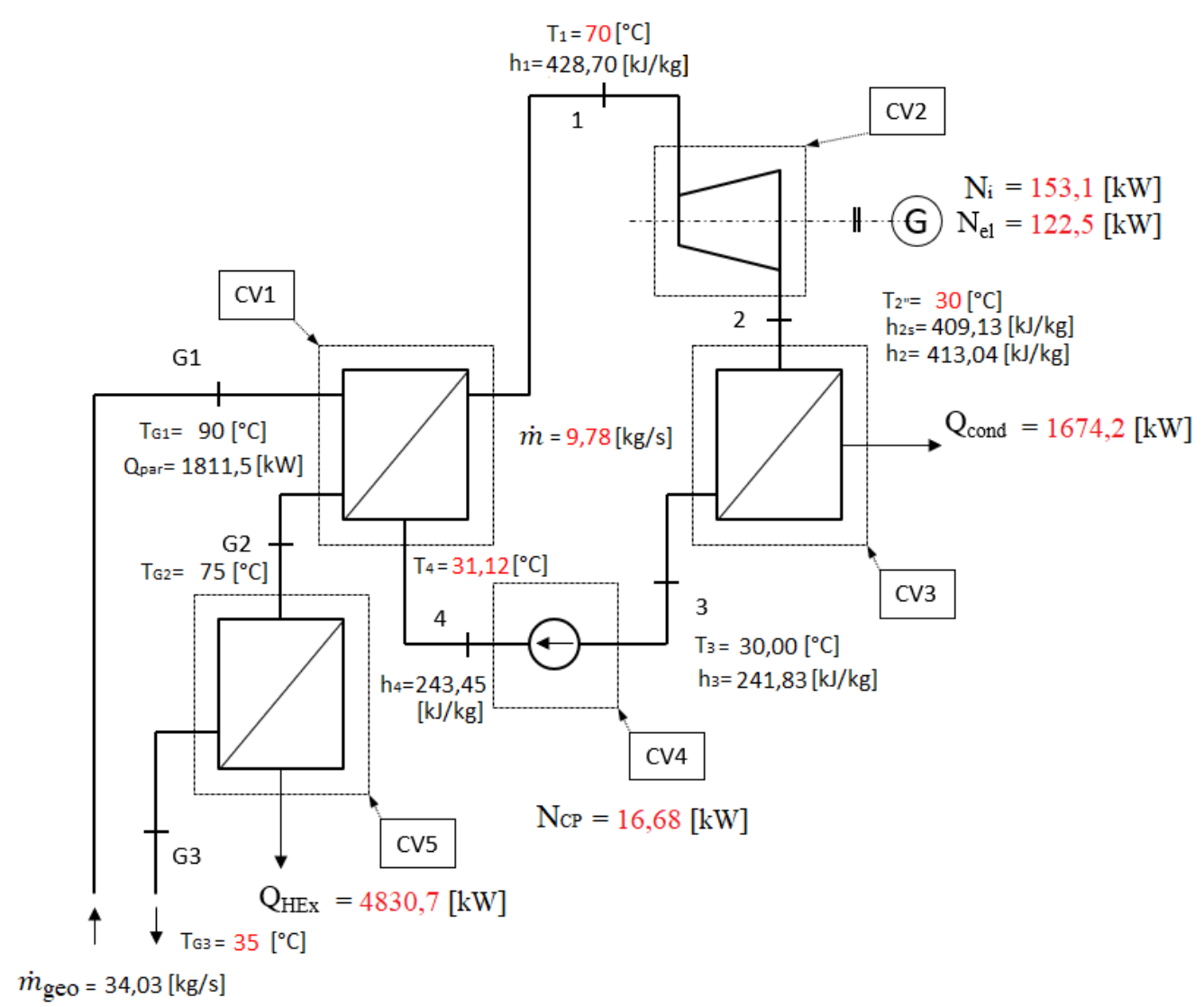

Fig. 5. Printscreen of Excel calculation tool for working fluid R134a and thermal parameters: $t_{1}=70^{\circ} \mathrm{C}, t_{2}{ }^{\prime \prime}=30^{\circ} \mathrm{C}, t_{G 3}=35^{\circ} \mathrm{C}$.

Table 4 presents the example of calculation data for working fluid R227 and following thermal parameters $t_{1}=70^{\circ} \mathrm{C}, t_{2 \prime \prime}=25^{\circ} \mathrm{C}, t_{G 3}=40^{\circ} \mathrm{C}$, and energy balance calculation results are shown in Fig. 6. 
Table 4. The thermodynamic properties of characteristic points for $R 227$

\begin{tabular}{ccccc}
\hline \multirow{2}{*}{ Point } & $\mathrm{p}$ & $\mathrm{t}$ & $\mathrm{v}$ & $\mathrm{h}$ \\
\cline { 2 - 5 } & {$[\mathrm{bar}]$} & {$\left[{ }^{\circ} \mathrm{C}\right]$} & {$\left[\mathrm{dm}^{3} / \mathrm{kg}\right]$} & {$[\mathrm{kJ} / \mathrm{kg}]$} \\
\hline 1 & 14,87 & 70,00 & 7,64 & 365,25 \\
\hline 2 & 4,56 & 39,80 & 29,79 & 353,28 \\
\hline $2 \mathrm{~s}$ & 4,56 & 36,42 & 29,30 & 350,29 \\
\hline $2^{\prime \prime}$ & 4,56 & 25,00 & 27,59 & 340,22 \\
\hline 3 & 4,56 & 25,00 & 0,72 & 228,84 \\
\hline 4 & 14,87 & 25,98 & 0,72 & 229,90 \\
\hline
\end{tabular}

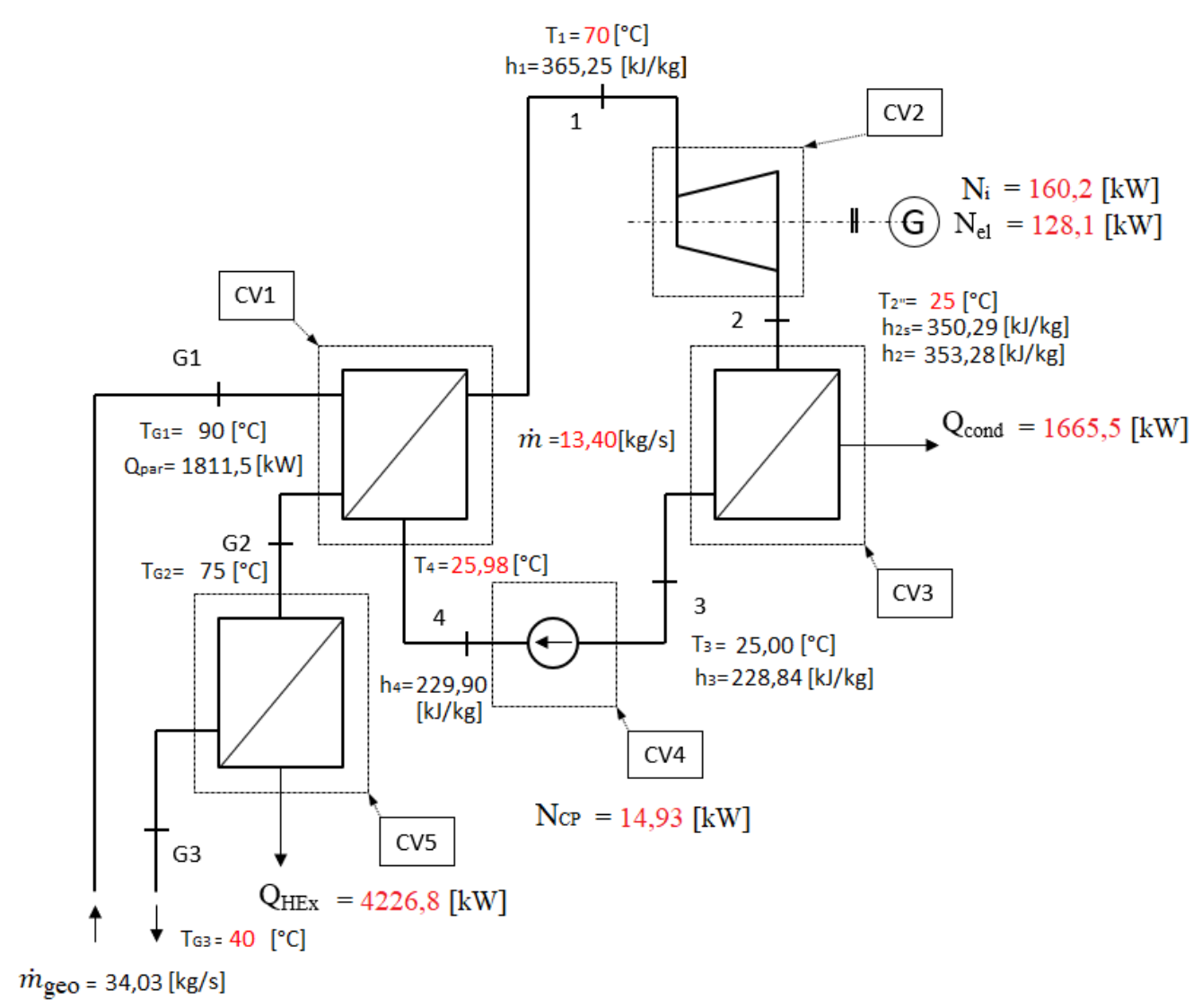

Fig. 6. Printscreen of Excel calculation tool for working fluid R227 and thermal parameters: $t_{1}=70^{\circ} \mathrm{C}, t_{2}^{\prime \prime}=25^{\circ} \mathrm{C}, t_{G 3}=40^{\circ} \mathrm{C}$.

Table 5 presents the summary of energy balance calculation results for all working fluids and operating paramteres. 
Table 5. Energy performance of ORC for different working fluids

\begin{tabular}{cccccccc}
\hline \multirow{2}{*}{$\begin{array}{c}\text { Working } \\
\text { fluid }\end{array}$} & $\mathrm{t}_{1}$ & $\mathrm{t}_{2 "}$ & $\dot{\mathrm{m}}$ & $\mathrm{N}_{\mathrm{i}}$ & $\mathrm{N}_{\mathrm{el}}$ & $\mathrm{Q}_{\text {skr }}$ & $\mathrm{N}_{\text {cp }}$ \\
\cline { 2 - 7 } & {$\left[{ }^{\circ} \mathrm{C}\right]$} & {$\left[{ }^{\circ} \mathrm{C}\right]$} & {$[\mathrm{kg} / \mathrm{s}]$} & {$[\mathrm{kW}]$} & {$[\mathrm{kW}]$} & {$[\mathrm{kW}]$} & {$[\mathrm{kW}]$} \\
\hline \multirow{3}{*}{ R123 } & 75 & 25 & 9,07 & 183,3 & 146,7 & 1631,1 & 3,15 \\
& 75 & 30 & 9,32 & 166,8 & 133,5 & 1647,7 & 3,14 \\
& 70 & 25 & 9,20 & 169,3 & 135,5 & 1644,7 & 2,71 \\
& 70 & 30 & 9,46 & 152,2 & 121,8 & 1661,7 & 2,59 \\
\hline \multirow{2}{*}{ R134a } & 75 & 25 & 9,41 & 182,7 & 146,2 & 1647,7 & 19,92 \\
& 75 & 30 & 9,77 & 167,1 & 133,7 & 1663,1 & 19,75 \\
& 70 & 25 & 9,42 & 169,4 & 135,5 & 1658,3 & 17,05 \\
& 70 & 30 & 9,78 & 153,1 & 122,5 & 1674,2 & 16,68 \\
\hline \multirow{2}{*}{ R227 } & 75 & 25 & 13,21 & 172,3 & 137,8 & 1655,5 & 17,24 \\
& 75 & 30 & 13,80 & 158,0 & 126,4 & 1669,8 & 17,14 \\
& 70 & 25 & 13,38 & 160,2 & 128,1 & 1665,5 & 14,93 \\
\hline
\end{tabular}

The influence of the temperature of geothermal water leaving heat exchanger (CV-5) on the heating capacity of district heating heat exchanger is shown in Table 6.

Table 6. Calculation results for heat exchanger (CV5) for different temperatures

of water leaving HEx

\begin{tabular}{ccccc}
\hline$t_{\mathrm{G} 2}$ & $t_{\mathrm{G} 3}$ & $\dot{m}_{g e o}$ & $\mathcal{c}_{w}$ & $\dot{Q}_{H E X}$ \\
\hline$\left[{ }^{\circ} \mathrm{C}\right]$ & {$\left[{ }^{\circ} \mathrm{C}\right]$} & {$[\mathrm{kg} / \mathrm{s}]$} & {$[\mathrm{kJ} /(\mathrm{kg} \mathrm{K})]$} & {$[\mathrm{kW}]$} \\
\hline 75 & 30 & 34,03 & 3,549 & 5434,5 \\
\hline 75 & 35 & 34,03 & 3,549 & 4830,7 \\
\hline 75 & 40 & 34,03 & 3,549 & 4226,8 \\
\hline
\end{tabular}

The calculation results show that for all three working fluids the highest production of electrical power refers to the evaporation temperature $t_{1}=75^{\circ} \mathrm{C}$ and condensation temperature $t_{2 \prime \prime}=25^{\circ} \mathrm{C}$. The differences are rather small, for R123 and R134a the electricity production is a little bit higher comparing with R227 working fluid. It is worth to underline that significant part of electricity production would be used for covering self-energy requirements of district heating system and ORC CHP plant.

In the case of heat the increase of temperature of geothermal water leaving heat exchanger $t_{G 3}$ significantly decrease the production of that form of useable energy. It has been assumed that geothermal CHP plant is capable to cover full requirements of heat end users.

\section{Energy and environment performance of geothermal CHP plant}

It has been assumed that for geothermal CHP plant the use of chemical enthalpy of fossil fuels and the emission of carbon dioxide are equal: $\dot{H}_{c h, G E O}=0 \mathrm{~kW}$ and $\dot{E}_{C O 2, G E O}=0 \mathrm{kgCO}_{2} / \mathrm{h}$. In order to 
evaluate energy performance of geothermal CHP plant the calculation of chemical enthalpy of fossil fuels use for typical (reference) energy system has been derived. In the case of environmental performance carbon dioxide emission for reference energy system has been calculated. As the reference energy system the separate production of heat in gas fired condensing boilers $\left(\eta_{C B}=100 \%\right)$ and electrical power in conventional steam condensing power plant fired with hard coal $\left(\eta_{P P}=33 \%\right)$, has been taken into consideration. Electrical power production and heat flux production have been taken the same as for geothermal CHP plant. The emission of carbon dioxide has been derived for hourly and annual conditions. It has been assumed that energy system has to operate for $\tau_{E L}=$ $8760 / a$ in the case of electrical power production and for $\tau_{H E X}=2000 \mathrm{~h} / \mathrm{a}$ in the case of heat production. The carbon dioxide emission factors for hard coal and natural gas have been taken as: $e_{\mathrm{CO} 2, \mathrm{HC}}=0,35 \mathrm{kgCO}_{2} / \mathrm{kWh}$ and $e_{\mathrm{CO}, \mathrm{NG}}=0,20 \mathrm{kgCO}_{2} / \mathrm{kWh}$.

Table 7. Chemical enthalpy of hard coal use and carbon dioxide emission in production

of electrical power for reference energy system

\begin{tabular}{cccccccc}
\hline \multirow{2}{*}{$\begin{array}{c}\text { Working } \\
\text { fluid }\end{array}$} & $N_{e l}$ & $N_{c p}$ & $N_{e l, n e t}$ & $\dot{H}_{c h, H C}$ & $\dot{E}_{C O 2, H C}$ & $H_{c h, H C}$ & $E_{C O 2, H C}$ \\
\cline { 2 - 7 } & {$[\mathrm{kW}]$} & {$[\mathrm{kW}]$} & {$[\mathrm{kW}]$} & {$[\mathrm{kW}]$} & {$\left[\mathrm{kgCO}_{2} / \mathrm{h}\right]$} & {$[\mathrm{MWh} / \mathrm{a}]$} & {$\left[\mathrm{MgCO}_{2} / \mathrm{a}\right]$} \\
\hline \multirow{3}{*}{ R123 } & 146,7 & 3,15 & 143,5 & 434,9 & 152,2 & 3809,7 & 1333,5 \\
& 133,5 & 3,14 & 130,3 & 395,0 & 138,2 & 3460,2 & 1211,0 \\
& 135,5 & 2,71 & 132,8 & 402,3 & 140,8 & 3524,1 & 1233,4 \\
& 121,8 & 2,59 & 119,2 & 361,1 & 126,4 & 3163,2 & 1107,2 \\
\hline \multirow{2}{*}{ R134a } & 146,2 & 19,92 & 126,2 & 382,6 & 133,9 & 3351,6 & 1172,9 \\
& 133,7 & 19,75 & 113,9 & 345,2 & 120,8 & 3024,0 & 1058,3 \\
& 135,5 & 17,05 & 118,5 & 359,0 & 125,6 & 3144,8 & 1100,8 \\
& 122,5 & 16,68 & 105,8 & 320,6 & 112,2 & 2808,5 & 983,0 \\
\hline \multirow{3}{*}{ R227 } & 137,8 & 17,24 & 120,6 & 365,5 & 127,9 & 3201,8 & 1120,5 \\
& 126,4 & 17,14 & 109,3 & 331,1 & 115,9 & 2900,4 & 1015,1 \\
& 128,1 & 14,93 & 113,2 & 343,1 & 120,1 & 3005,6 & 1051,8 \\
& 116,2 & 14,73 & 101,4 & 307,4 & 107,6 & 2692,8 & 942,5 \\
\hline
\end{tabular}

Table 8. Chemical enthalpy of natural gas use and carbon dioxide emission in production of heat in reference energy system

\begin{tabular}{ccccccc}
\hline$t_{G 2}$ & $t_{G 3}$ & $\dot{Q}_{H E X}$ & $\dot{H}_{c h, N G}$ & $\dot{E}_{C O 2, N G}$ & $H_{c h, N G}$ & $E_{C O 2, N G}$ \\
\hline$\left[{ }^{\circ} \mathrm{C}\right]$ & {$\left[{ }^{\circ} \mathrm{C}\right]$} & {$[\mathrm{kW}]$} & {$[\mathrm{kW}]$} & {$\left[\mathrm{kgCO}_{2} / \mathrm{h}\right]$} & {$[\mathrm{MWh} / \mathrm{a}]$} & {$\left[\mathrm{MgCO}_{2} / \mathrm{a}\right]$} \\
\hline 75 & 30 & 5434,5 & 5434,5 & 1086,9 & 10869,0 & 2173,8 \\
75 & 35 & 4830,7 & 4830,7 & 966,1 & 9661,4 & 1932,3 \\
75 & 40 & 4226,8 & 4226,8 & 845,4 & 8453,6 & 1690,7 \\
\hline
\end{tabular}

It can be seen (Tables 7 and 8) that construction of geothermal CHP plan can significantly reduce the chemical enthalpy of fossil fuels use and emission of carbon dioxide what is of greatest importance concerning poor performance of energy systems in Poland. The total annual use of fossil fuels 
chemical enthalpy and carbon dioxide emission for reference energy system have been calculated using following equations:

$$
\begin{gathered}
H_{c h}=H_{c h, H C}+H_{c h, N G} \\
E_{C O 2}=E_{C O 2, H C}+E_{C O 2, H C}
\end{gathered}
$$

Where:

$$
\begin{array}{lll}
H_{c h} & -\quad \text { total annual use of fossil fuels for reference energy system, } \mathrm{MWh} / \mathrm{a} \\
E_{\mathrm{CO} 2} & -\quad \text { total annual emission of } \mathrm{CO}_{2} \text { for reference energy system, } \mathrm{MgCO}_{2} / \mathrm{a}
\end{array}
$$

The calculations have been performed for all three working fluids and 12 discrete temperature conditions of ORC CHP plant operation listed in Table 9.

Table 9. Discrete temperature conditions (DTC) for energy and ecological analysis of ORC CHP plant operation

\begin{tabular}{ccccc}
\hline$D T C$ & $t_{1}$ & $t_{2}{ }^{\prime \prime}$ & $t_{G 2}$ & $t_{G 3}$ \\
\hline$[-]$ & {$\left[{ }^{\circ} \mathrm{C}\right]$} & {$\left[{ }^{\circ} \mathrm{C}\right]$} & {$\left[{ }^{\circ} \mathrm{C}\right]$} & 30 \\
\hline 1 & 75 & 25 & 75 & 35 \\
2 & 75 & 25 & 75 & 40 \\
3 & 75 & 25 & 75 & 30 \\
\hline 4 & 75 & 30 & 75 & 35 \\
5 & 75 & 30 & 75 & 40 \\
\hline 6 & 75 & 30 & 75 & 30 \\
\hline 7 & 70 & 25 & 75 & 35 \\
9 & 70 & 25 & 75 & 40 \\
11 & 70 & 25 & 75 & 30 \\
12 & 70 & 30 & 75 & 35 \\
\hline
\end{tabular}

The results of calculations have been plotted in Fig. 7 and Fig. 8. 


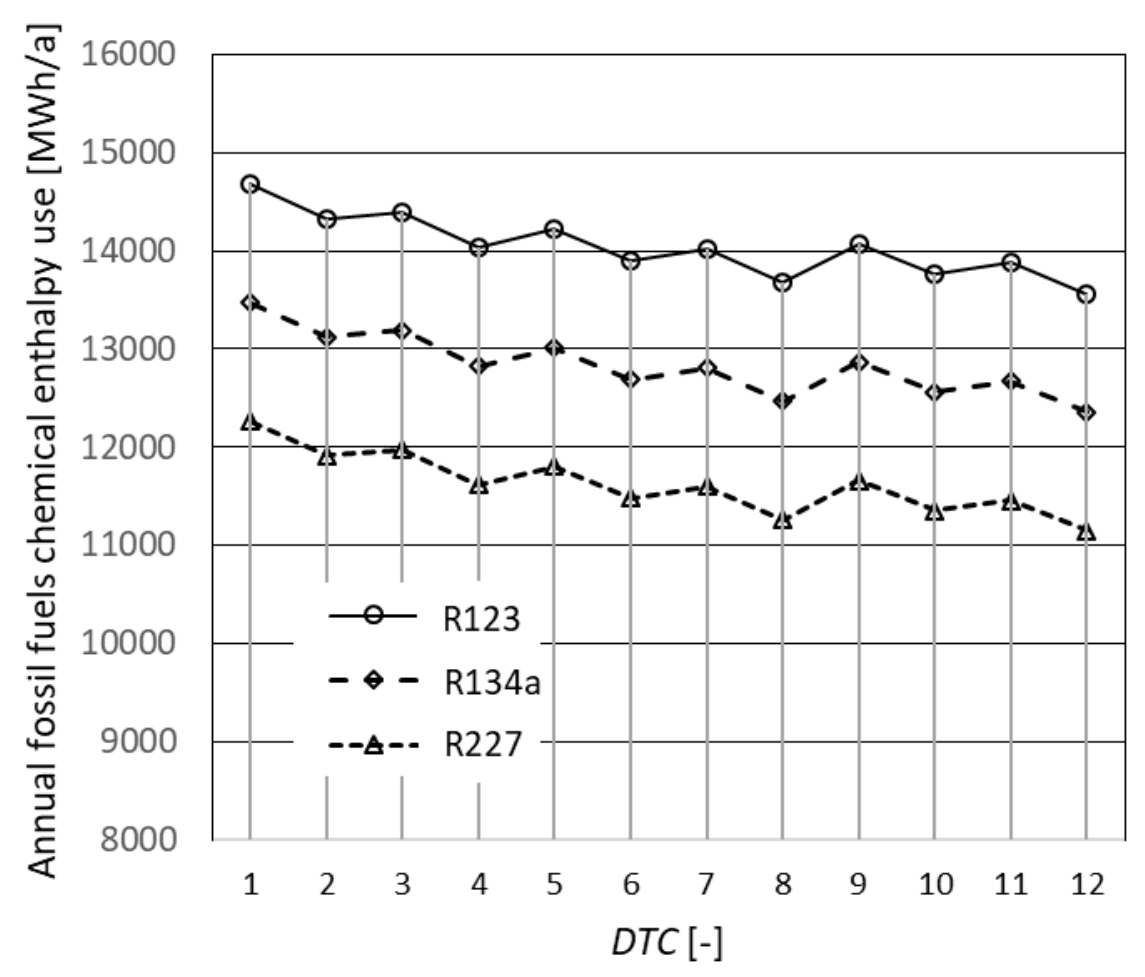

Fig. 7. Total annual use of fossil fuels for reference energy system

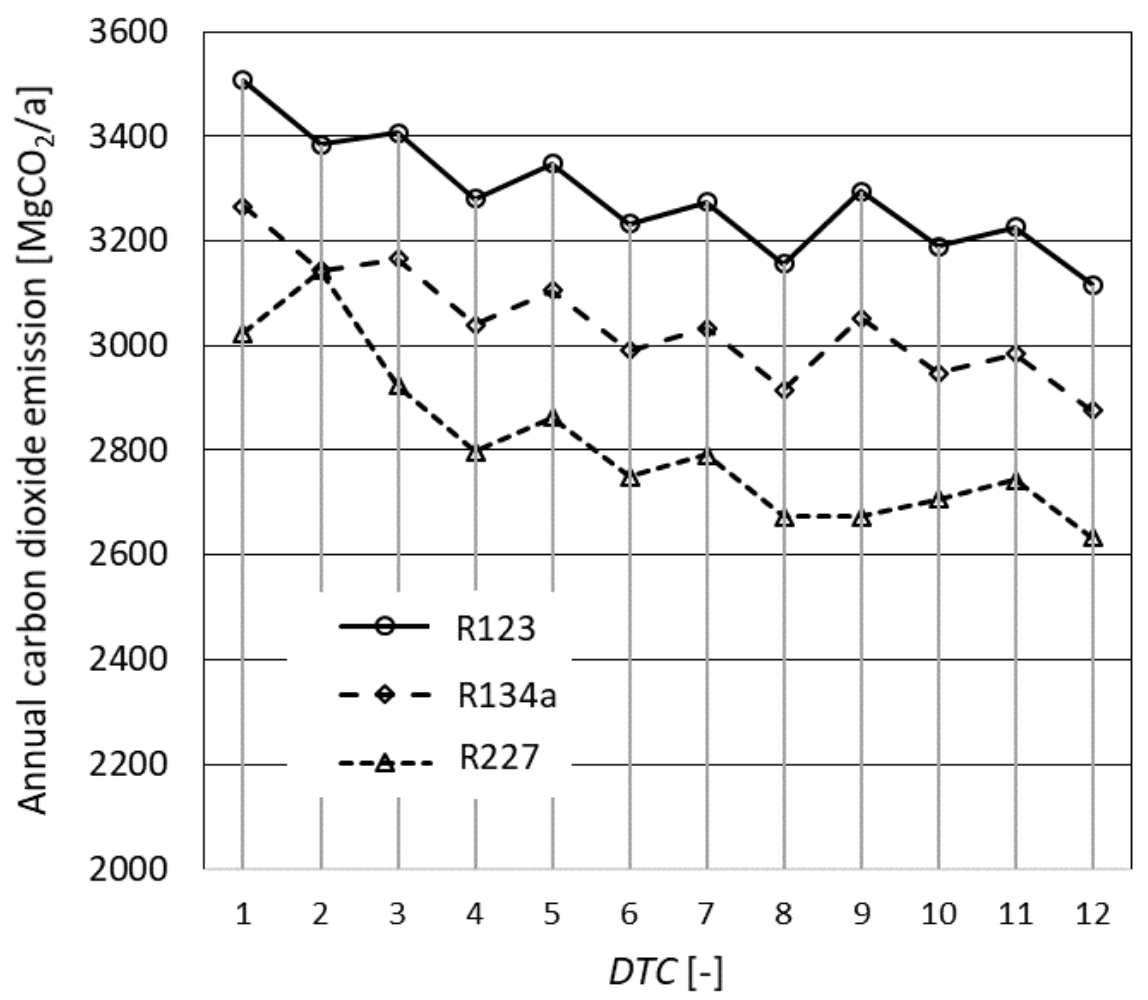

Fig. 8. Total annual emission of carbon dioxide for reference energy system 
It can be seen in Fig. 6, that application of ORC based geothermal CHP plant can significantly reduce annual consumption of chemical enthalpy of fossil fuels. The best energy performance can be spotted for working fluid R123, for which the reduction varies between 14700 and $13600 \mathrm{MWh} / \mathrm{a}$. The working fluid R134a has a worse energy performance, which allows for the reduction of fossil fuels energy consumption in the range of 13500 and $12300 \mathrm{MWh} / \mathrm{a}$. The worst performance has been noted for working fluid R227 - the reduction between 12200 and $11100 \mathrm{MWh} / \mathrm{a}$. The same relation concerning ecological performance - the reduction of carbon dioxide emission, can be found - see Fig. 7. The total reduction of $\mathrm{CO}_{2}$ emission is the highest for working fluid R123: 3500 to 3120 $\mathrm{MgCO}_{2} / \mathrm{a}$, the medium one for working fluid R134a: 3260 to $2870 \mathrm{MgCO}_{2} / \mathrm{a}$ and the lowest for working fluid R227: 3160 to $2620 \mathrm{MgCO}_{2} / \mathrm{a}$.

In all the cases the reduction can be regarded as significant from the point of view energy and ecological performance of energy systems in Poland, thus it should be taken into consideration instead utilization of geothermal energy in the production of heat only.

\section{Conclusions}

The aim of the work was to propose the conceptual design of geothermal CHP plant that would be applicable in Poland. Bearing in mind the geothermal conditions prevailing in Poland the use of ORC seems to be the only one reasonable solution. The energy and environment evaluation of geothermal CHP plant based on ORC has been conducted. The evaluation referred to the existing geothermal well located in the city of Konin in Wielkolpolska voivodship, the central part of Poland . It has been assumed that the system is capable to cover heat and electrical power of energy end users, thus does not require additional energy sources. Such a system is characterized by zero chemical enthalpy of fossil fuels use and zero carbon dioxide emission. Nevertheless that electrical power production is not high the use of ORC can significantly reduce the emission of carbon dioxide comparing with traditional energy systems based fossil fuels and separate production of heat and electrical power. The amount of heat production highly depends on the thermal parameters of heat exchanger operation. The lower is the temperature of heat exchanger operation the higher is production of heat. On the other hand the decrease of that temperature determines the need of installation of low temperature heating systems in end users what can be difficult concerning economical and organizational aspects.

It has been shown that construction of geothermal CHP plants based on Organic Rankine Cycle can be reasonable solution in polish conditions. It is of greatest importance concerning poor performance of energy systems in Poland.

Authors Contributions: TM WG

Funding: TM WG

Acknowledgment: TM WG

Conflicts of Interest: TM WG 


\section{Nomenclature}

\begin{tabular}{|c|c|c|}
\hline$c_{w}$ & - & specific heat of geothermal water, $\mathrm{kJ} / \mathrm{kg}^{\circ} \mathrm{C}$ \\
\hline$e_{\mathrm{CO} 2}$ & - & carbon dioxide emission factor for fossil fuel, $\mathrm{kgCO}_{2} / \mathrm{kWh}$ \\
\hline$\dot{E}$ & - & energy flux, kW \\
\hline$\dot{E}_{\mathrm{CO} 2}$ & - & carbon dioxide emission, $\mathrm{kg} / \mathrm{h}$ \\
\hline$\dot{H}_{c h}$ & - & chemical enthalpy flux of fossil fuel, $\mathrm{kW}$ \\
\hline$h_{G, i}$ & - & specific enthalpies of geothermal water, $\mathrm{kJ} / \mathrm{kg}$ \\
\hline$h_{G, i}$ & - & specific enthalpies of geothermal water, $\mathrm{kJ} / \mathrm{kg}$ \\
\hline$\dot{m}$ & - & mass flow, $\mathrm{kg} / \mathrm{s}$ \\
\hline$N_{c p, i}$ & - & internal power of ORC circulating pump, $\mathrm{kW}$ \\
\hline$N_{c p}$ & - & electrical power of ORC circulating pump, $\mathrm{kW}$ \\
\hline$N_{i}$ & - & internal power of ORC turbine, $\mathrm{kW}$ \\
\hline$N_{e l}$ & - & electrical power of ORC turbine, $\mathrm{kW}$ \\
\hline$p_{i}$ & - & pressure of ORC working fluid, $\mathrm{kPa}$ \\
\hline$v$ & - & specific volume of ORC working fluid, $\mathrm{m}^{3} / \mathrm{kg}$ \\
\hline$\eta_{c p, i}$ & - & internal energy efficiency of ORC circulating pump, \\
\hline$\eta_{c p, e m}$ & - & electro-mechanical energy efficiency of ORC circulating pump, \\
\hline$\eta_{e m}$ & - & electro-mechanical energy efficiency of ORC turbine, \\
\hline
\end{tabular}



$\tau_{E L} \quad-\quad$ equivalent number of hours of electricity production per year, $\mathrm{h} / \mathrm{year}$
$\tau_{H E X} \quad-\quad$ equivalent number of hours of heat production per year, $\mathrm{h} / \mathrm{year}$

\section{Indices}

\begin{tabular}{|c|c|c|}
\hline$c p$ & - & circulating pump \\
\hline cond & - & condenser \\
\hline em & - & electro-mechanical \\
\hline evap & - & evaporator \\
\hline geo & - & geothermal water \\
\hline$H C$ & - & hard coal \\
\hline$H E X$ & - & heat exchanger \\
\hline$N G$ & - & natural gas \\
\hline
\end{tabular}

\section{References}

1. Dai X. ; Shi L. ; Qian W., Thermal stability of hexamethyldisiloxane (MM) as a working fluid for organic Rankine cycle, International Journal of Energy Research, 2019, vol.43 (2), pp. 896- 899 .

2. Barbacki A., Pająk L., Assessment of Possibilities of Electricity Production in Flash Geothermal System in Poland, Geomatics and Environmental Engineering, Volume 11, Number 3, 2017, pp.17-29

3. Feng Yong-Qiang; Hung Tzu-Chen; He Ya-Ling ; Wang Qian ; Chen Shih-Chi ; Wu ShangLun ; Lin Chihhung, Experimental investigation of lubricant oil on a $3 \mathrm{~kW}$ organic Rankine cycle (ORC) using R123, Energy Conversion and Management, 2019, vol. 182, pp.340-350.

4. Grabowska W., Utilization of geothermal energy in co-generated heat and power production, Eng. Thesis, Poznan University of Technology, Poznań 2019 (in polish)

5. http://www.exergy-orc.com

6. https://infobasen.pl/ 
7. https://www.pgi.gov.pl/kopalnia-wiedzy/128-energia-geotermalna/1739-wody-termalneniiu-polskiego.html

8. https://www.turboden.com/turboden-orc-technology/1062/the-orc-technology

9. Jankowski M. ; Borsukiewicz A. ; Szopik-Depczyńska K. ; Ioppolo G., Determination of an optimal pinch point temperature difference interval in ORC power plant using multiobjective approach, Journal of Cleaner Production, 2019, vol. 217, pp. 798-807.

10. Kępińska B., Review of geothermal energy utilization in Poland between 2013-2015, Technology of Geological Survey. Geothermy. Sustainable Development 2016, vol. 1, pp.1934 (in polish).

11. Liu L. ; Zhu T. ; Wang T. ; Gao N., Experimental investigation on the effect of working fluid charge in a small-scale Organic Rankine Cycle under off-design conditions, Energy, 2019, vol. 174, pp. 664-677.

12. Michałowski M., Environmentally-friendly use of geothermal energy in Poland, Journal of the Polish Mineral Engineering Society, July-December 2011, pp. 1-9

13. Michałowski M., Saran E., Wójcik A., Geothermal Energy in Uniejów - Characteristics, Journal of the Polish Mineral Engineering Society, June-January 2015, pp.127-132

14. Nowak W., Borsukiewicz-Gozdur A., ORC power stations as the solution of low temperature heat source utilization, Clean energy, 2011, vol. 2., pp.32-35

15. Quoilin S., Van Den Broek M., Declaye S., Dewallef P., Lemort V., Techno-economic survey of Organic Rankine Cycle (ORC) systems, Renewable and Sustainable Energy Reviews, 2013, vol. 22, pp. 168-186.

16. Rettig A., Lagler M., Lamare T., Li S., Mahadea V., McCallion S., Chernushevich J., Application of Organic Rankine Cycles (ORC), World Engineers' Convention 2011, Geneva 4-9 September.

17. Strzelczyk F., Geothermal energy and heat pumps, Kielce University of Technology, Kielce 2017 (in polish).

18. Wang S. ; Liu C. ; Liu L. ; Xu X. ; Zhang C., Ecological cumulative exergy consumption analysis of organic Rankine cycle for waste heat power generation, Journal of Cleaner Production, 1 May 2019, Vol.218, pp. 543-554.

19. www.geotermiakonin.pl/odwiert-geotermalny.html

20. Zanellato L. ; Astolfi M. ; Serafino A. ; Rizzi D. ; Macchi E., Field performance evaluation of geothermal ORC power plants with a focus on radial outflow turbines, IV International Seminar on ORC Power Systems, ORC2017 13-15 September 2017, Milano, Italy, pp.1-8.

21. Zhang H. ; Guan X. ; Ding Y. ; Liu C., Emergy analysis of Organic Rankine Cycle (ORC) for waste heat power generation, Journal of Cleaner Production, 10 May 2018, Vol.183, pp. 1207-1215.

Author Contributions: conceptualization, T.M.; methodology, T.M. and W.G.; formal analysis, T.M. and W.G.; investigation, W.G. and T.M.; resources, W.G.; writing-original draft preparation, T.M. and W.G.; writing-review and editing, T.M.; visualization, W.G.; supervision, T.M.

Funding: This publication was funded by the Polish Ministry of Science and Higher Education, research subsidy number 01/13/SBAD/0912.

Acknowledgments: This work is based on the results of Weronika Grabowska's Eng. thesis entitled "Utilization of geothermal energy in co-generated production of heat and power" (original title: "Wykorzystanie energii geotermalnej w skojarzonej produkcji ciepła i energii elektrycznej") under the supervision of Prof. Tomasz Mroz. 
Conflicts of Interest: The authors declare no conflict of interest. The funders had no role in the design of the study; in the collection, analysis, or interpretation of data; in the writing of the manuscript; or in the decision to publish the results. 